\title{
Cultural literacy building of primary school students as basic concept
}

\author{
Ma'as Sobirin \& Peni Susapti \\ Universitas Wahid Hasyim Semarang \\ IAIN Salatiga \\ maas.shobirin@unwahas.ac.id.
}

DOI: 10.18326/mudarrisa.v10i2.206-221

\begin{abstract}
The low literacy ability of the society will have an impact on the quality of human resources. Nowadays, literacy (read-write) has not yet become a necessity of life and part of nation's culture. Schools as the primary means of shaping the character of students need to plan programs that lead to literacy culture as a solution to the problem. Currently, schools are busy implementing government programs through literacy programs with the aim of the growing awareness of students in familiarizing the culture. This program provides the significant influence for students with various forms of activities undertaken by school. On this occasion, the writer tries to present some explanations related to the basic concepts, urgency, stapes of cultural development of literacy and the form of programs that can be done in supporting of literacy culture in Elementary School.
\end{abstract}

Keywords: culture, literacy, elementary school 


\section{Mudarrisa: Jurnal Kajian Pendidikan Islam, Vol. 10, No. 2, 2018}

\section{INTRODUCTION}

One of the serious problems faced by the Indonesian people is the lack of literacy (reading and writing) skills of the people, especially among students. In essence, literacy is a valuable activity as a form of optimizing the ability to think and express ideas through writing that will affect the behavior of human life. Thus, literacy is an important part of activities in developing the potential of human reason. Knowledge can be explored quickly and information is obtained in an easy way, in line with the conditions that occur in the field. However, the community is not yet fully aware that the tradition of literacy is a basic need for humans in productive activities. Subekti Makdriani, a librarian of the Republic of Indonesia Library (RI), explained that the reading interest of the Indonesian people was ranked 60th out of 61 countries based on the 2016 Most Littered Nation in The World Study in which most of the time caused by oral culture.

In 2000, in terms of literacy, Indonesia was ranked 39th out of 41 countries; 2003 it was ranked 39 out of 40 countries; in 2006 ranked 48th out of 56 countries; in 2009 ranked 57th out of 65 countries; in 2015 there were 69 out of 76 countries (Bambang, 2006: 68). Research on literacy conducted by Central Connecticut State University in New Britain, United States, places five countries with the best literacy skills including Finland, Norway, Iceland, Denmark, and Sweden (The Jakarta Post, March 12, 2016). This data should be a reference for all parties to improve the pattern of education that is always far from achieving 


\section{Mudarrisa: Jurnal Kajian Pendidikan Islam, Vol. 10, No. 2, 2018}

children's competency in literacy. Technology in literacy improvement is needed to support students' ability in decision making related to the learning process (Rambousek, et. al., 2016: 355; Yamtim \& Wongwanich, 2014: 2999).

Mulyo Teguh (2017: 1) explains that the low literacy capacity of society will have an impact on human quality and lack of mastery of science and technology. Literacy tradition has not yet reached the level of the Indonesian people's needs and culture. The number of libraries and collections of digital books and information in Indonesia is still minimal to meet the reading needs for the Indonesian.

Suragangga (2017) argues that the increasingly competitive world as it is today, demands its generation to be smart, creative, and innovative. All of these skills can be realized, one of them through creative reading activities. The demands of this century make young people thirst for reading both from within and outside the country. Reading is an easy activity, but it is difficult to become a habit. Youngsters believe that this is a boring and saturated activity. There is a demand of serious efforts as literacy is very crucial element in developing a nation. If the current generation has a low level of literacy, then this nation will find it difficult to be a better generation in the future.

Educational institutions play a very important role in shaping better mindset for young generation. Thus, Elementary School / Madrasah Ibtidaiyah (MI) needs to design programs that encourage the creation of a climate that supports the tradition of literacy. In other words, schools need 


\section{Mudarrisa: Jurnal Kajian Pendidikan Islam, Vol. 10, No. 2, 2018}

to make the whole process and series of teaching and learning as a part of building literacy culture.

The government responded quickly to overcome this problem. Furthermore, the Ministry of Education and Culture launched a School Literacy Movement (GLS) program that involved all stakeholders in the education sector, from the central, provincial, district/city level, to the education unit level. In addition, the involvement of several external elements, such as parents, alumni, the community, entrepreneurship is also an important element in the GLS program (Faizah, et al., 2016: 1)

These efforts are carried out to improve the quality of education and human resources fostering a generation that is fond of literacy to meet the need for information and technology era for the better generation. Developing this awareness should be started from the very early time so that educational institutions are able to design programs in schools/ madrasah focusing on reading and writing.

This study presents several explanations regarding the basic concepts, urgency, stages of developing literacy culture and the form of programs that can be carried out in the elementary school environment. The novelty in this study will give the idea that educators are able to study and implement the GLS program with full responsibility and have implications for the literacy culture of students in elementary school/ Madrasah Ibtidaiyah (MI). 


\section{METHODS}

This research used literature review methods. Some researches discussing literacy as the focus had been reviewed, especially for digital literacy for sciences study.

\section{DISCUSSION}

\section{Basic Concept of Literacy}

Literacy is a term that is often heard by educators. However, only a few really understand the meaning of the term. This is because the term of literacy is a concept that is broad, meaningful, and interpreted in various ways. Therefore, it is necessary to further understand literacy, especially those that are still closely related to the world of education. Koichiro (2005: 158) defined literacy as learning to read and write (text and numbers) and also about reading, writing and counting to learn, and developing these skills and using them effectively for meeting basic needs. Reading, writing and counting are very important activities in life as a form of developing one's skills and knowledge. Good literacy skills will be gained when someone focuses on doing that and in simultaneous efforts.

In understanding literacy, there are actually several basic concepts in which it is not only limited to reading and writing. According to Mulyo Teguh (2017: 3) the basic concepts are as follows:

Basic Literacy

Typical literacy develop here is reading, writing and counting. These are activities mostly done by studying in elementary students. But under 


\section{Mudarrisa: Jurnal Kajian Pendidikan Islam, Vol. 10, No. 2, 2018}

certain conditions, even adults will also need these activities as a means of enhancing knowledge and completing tasks of their responsibility. Further, the ability of students to listen, understands spoken language, and communicates through images and oral forms are formed by the interactions with their social environment at home. The experience of students in communicating on mother tongue is a basic literacy capital.

\section{Library Literacy}

The library has become the center of the spirit of knowledge at all levels of education, both from the basic and tertiary levels. At present, the library does not only function as a place to store books and scientific works, but also can carry out scientific activities in the framework of scientific development, such as discussions, workshops, training and so on, thus the library becomes the center of scientific activities in an educational institution. Further, it also provides explanations to distinguish between fiction and nonfiction reading, reference use and periodically understand Dewey Decimal Systems as a classification of knowledge that facilitates library functioning, cataloging, and indexing.

\section{Technology Literacy}

In this component, educators are required to be familiar with technology. Scientific development must be accompanied by technological development that increasingly encourages people to explore knowledge that is broad and not limited by space. This enables educator to access all information available in various parts of the world (Rambousek et al., 2016: 326). Through the internet, for example, people do not need to 


\section{Mudarrisa: Jurnal Kajian Pendidikan Islam, Vol. 10, No. 2, 2018}

worry about looking for their physical books, but simply by downloading an e-book that is already available.

Media Literacy

Media can be divided into online media and print media. Both of these media are very instrumental in fostering the spirit of public literacy, especially in the field of education, online media such as Facebook, Twitter can be used to store archives of students' work. The teacher can also communicate with students at anytime and anywhere. While printed media in the form of newspapers can provide special columns for student work, such as poetry, free writing and so on.

Visual Literacy

Visual literacy is the ability a person has to explain actions, objects, and or visual symbols. In other terms, visual literacy is the ability to digest information presented in visual form. Of the various kinds of concepts that exist in literacy in the field of education, there are still many opportunities for educators to strive for learning environment so that literacy becomes part of routine activities that can be applied in the elementary school. In this activity, the role and involvement of various parties such as teachers, parents, library managers, and local governments is very important as a medium for students to better know and understand these habituation activities. 


\section{Mudarrisa: Jurnal Kajian Pendidikan Islam, Vol. 10, No. 2, 2018}

\section{The Importance of Literacy Culture at Primary School}

Implementing the literacy culture for students are the responsibility of all school members. Literacy is believed as the starting gate to open all knowledge through various fields of study. The habituation of literacy culture needs to be started at an early age since: home and at school. Without this habit, it will be very difficult to master the knowledge and technology which are all in books (Sutrisno, 2009: 2). Thus, schools are expected to be able to design teaching and learning activities elaborating these literacy habituations.

Reading and writing habits are connected each other. Reading will increase knowledge and information, while writing activities are intellectual traces or knowledge that can benefit others. Students with literacy abilities are believed to develop the nations into a better condition. A nation with excellent human resources will be better than a nation which is rich in natural resources.

Student literacy skills are a blend of basic literacy, library, media, technology and visual. Furthermore, the ability to develop those literacies into information literacy provides an understanding of information being read or written critically, analytically, and reflective (Ferguson, 2016: 9; Demirel \& Caymaz, 2015). That is what further makes literacy skills significant in facing the millennial era.

Permendikbud No. 232015 has pointed out the importance of developing a student literacy culture through a policy of reading 15 minutes before the lesson begins. Yet, it is not easy to make this program 


\section{Mudarrisa: Jurnal Kajian Pendidikan Islam, Vol. 10, No. 2, 2018}

successful. There is the need to make this as a habit for students. All of parties involved in the education should also appreciate the program the government planned. This program will be successful if the society realize the importance of literacy habituation and start to implement that within their inner circle family. Supiandi (2016: 6) also emphasizes that these literacies could shape students positive characteristics as critical, communicative, and creative. Besides aiming to shape character, literacy culture also aims to make the school truly become a learning community.

\section{Stages in Developing the Literacy Culture at Elementary School}

Implementing this culture is actually easy for schools since the government has given some rigid guidelines. In this section, the author will explain several stages of the guidelines, referring to namely the development of literacy culture for students in elementary school referring to the Desain Induk Gerakan Literasi Sekolah (2016: 28-27) as follows:

Habit for Fun Reading at School

This aims at fostering students interests in reading at school. Reading habit is the most crucial habit to be slowly developed for students. It will be very hard at the beginning for sure, but slowly it will have positive impact for students. The stages are as the following:

- Students should read 15 minutes before the lesson begun. They can read aloud or do sustained silent reading

- making the school as creative literacy environment by (a) completing the needs of the library, making a special reading area 
in each corner of the building that is relatively comfortable; (b) developing other facilities by making inspirational writings; (c) the addition of easily accessible books, visuals, digital and multimedia collections; (d) the production of print-rich materials attached to the classroom walls.

Developing Reading Interest to Improve Literacy Abilities

Literacy activities at this stage aim at developing the ability to understand reading and to relate it to the experiences of students while at the same time processing them by responding to the reading. This process can be done every day at the school. On the other hand, it is necessary to provide facilities that can develop children's reading interest in the school environment. There are some stages in improving students' interest in reading:

- Guided reading before the class started. Do this activity together and can be followed by additional non-academic tasks such as making mind maps of the stories read.

- Creating such a supportive school environment to reading such as first, by giving rewards to students with positive attitudes and with good achievements. Those students can be done after the flag ceremony so that other students can be motivated. Second, the school can create academic activities supporting this literacy.

- Developing this literacy by various activities at the library or creating reading corners in the school surrounding. The activities could be reading aloud, watching movies, reading visual books, 


\section{Mudarrisa: Jurnal Kajian Pendidikan Islam, Vol. 10, No. 2, 2018}

responding to fictions and non-fictions texts, drawing or discussing a book.

The implementation of Literacy-based Learning

This phase aims at fostering the understanding of the text and processing communication skills well through activities to respond to text enrichment reading books and textbooks. In this stage there are tasks that are academic in nature. Reading activities at this stage are to support the implementation of the 2013 Curriculum which requires students to read books outside the subject matter which can be in the form of fiction or non-fiction books, and can be linked to 6 subjects for elementary students. The teacher prepares the book used as a report on reading activities. These stage activities are as the following:

- 15 minutes reading before the class begin: co-reading and guided reading followed by academic and non-academic activities.

- Literacy activities are adjusted to 2013 Curriculum tasks.

- Understanding the textbooks by all means.

- Using school's physical, social-affective, and academic environment combined with various readings (non textbooks) to enhance students' knowledge.

In addition to those stages, Beers (2016:11) explained that the application of literacy culture has 7 principles that can be done. The principle includes (a) the development of literacy goes in line to the predicted stages of development, (b) balanced-literacy programs, (c) literacy programs in all curricula, (d) there is no term too much reading and writing, (e) discussion 


\section{Mudarrisa: Jurnal Kajian Pendidikan Islam, Vol. 10, No. 2, 2018}

and the use of mother tongue, ( $\mathrm{f}$ ) diversity must be created in class and school.

\section{Implementation of Literacy-Based Programs in Primary Schools}

In this section, the author provides some steps in strengthening literacy habituation in schools. The school is deemed necessary to promote programs that lead to literacy movements. This is believed to focus all the abilities possessed by school members achieve succession this literacy. The programs that can be held in elementary schools can be presented in the program as the following:

Literacy journals

A literacy journal is a journal that monitors the extent to which students carry out reading and writing activities with controls that can be done by parents, teachers, librarians, or peers (depending on students reading books, whether at home, school, library, or when study group with friends). This also helps teacher giving additional point for students' score for Indonesian subject using the concept of converted score. The conversion is 50 points for $1-2$ books, 60 points for $3-4$ books, 70 points for 5-6 books, 80 points for 7-8 books and 90 points for $9-10$ books. The points is to be given to the teacher who will put it on literacy assessment column which subsequently functioned to determine the final value of Indonesian language subjects, by bringing proof of the book read to the Indonesian teacher. The components in literacy journals are numbers, titles, books (e-books/print), authors and publishers of books, pages of 


\section{Mudarrisa: Jurnal Kajian Pendidikan Islam, Vol. 10, No. 2, 2018}

books, pages of books that are read, reasons for reading books, the benefits of reading the book, and initials of parents (Supiandi, 2016: 12). Thus, the teacher can record the progress made by students.

Literacy Zone

This means as class atmosphere motivating students to express students ideas thought writings. The most common item of this zoning is wall magazine located at the back part of the class. Students are expected to be brave in presenting their work in term of poetry, short stories and other literary works. Tteachers and headmasters should support this activity. To sum up, it can be done by giving a special place in the form of a board or the like to attach the work of students. The making mechanism can be done in groups and in turns. Each group once gets a turn to produce works are readible eat can be read by residents in the class. The teacher should provide the writing guidelines, both conceptual and technical.

Literacy Competition

The spirit in making literacy as a tradition should be echoed at every school member so that everyone focuses on this issue. Teachers and students have the same task in succeeding the literacy culture program. After completing literacy through various activities in the classroom, it is important to design the activities involved. The purpose of organizing literacy activities is to measure the progress or impact of the program on students' literacy skills. In general, this activity is designed as other competitions. The competition can be done by involving participants from internal and external. The competition can be in the form of poetry 


\section{Mudarrisa: Jurnal Kajian Pendidikan Islam, Vol. 10, No. 2, 2018}

reading competitions, news competition, speeches, or others. This activity is done to motivate students to be more serious in literacy activities at school. If student's literacy improves though these activities, the literacy program has run well at school.

Literacy Tour

Efforts to improve students' literacy skills in elementary schools should not only stop in the schools. There is a need to see how other schools or other institutions performing this literacy as the benchmark for improvement. The school can design a comparative activity in literacy program to other schools, regional public libraries, book store visits, newspaper visits, or book publisher visits. The knowledge gathered from these visits could be used as a valuable feedback to the literacy programs.

\section{CONCLUSION}

From the above discussion, literacy could be divided into several categories: basic, library, technology, media and visual literacy. There are some stages in developing those literacies are habituation, development and implementation. Those are then followed up by creating literacy programs such as literacy zones, literacy journals, literacy competitions, and literacy tourism. The government and the school could hand in hand focus in building and succession the programs. As the suggestions, the school should be serious in implementing literacy programs. Thus, the school helps the government succession the program. There is a demand of program evaluation done by district UPTP or Dinas Pendidikan to 
achieve the optimal outputs. Thus, the government should provide all the facilities needed during the program implementation. Besides, the government also needs to train the school principals as well as the teachers to have the same perceptions in running this literacy program.

\section{REFERENCES}

Bambang, T. (2016). Melejitkan Daya Literasi Indonesia: Sebuah Kajian Pendahuluan, Jakarta: Institut Penulis Indonesia.

Demirel, M., \& Caymaz, B. (2015). Prospective Science and Primary School Teachers' Self-efficacy Beliefs in Scientific Literacy. Procedia - Social and Behavioral Sciences, 191, 1903-1908.

Faizah, dkk., (2016). Panduan Gerakan Literasi di Sekolah Dasar, Jakarta: Direktorat Pembinaan Sekolah Dasar Direktorat Jenderal Pendidikan Dasar dan Menengah Kementerian Pendidikan dan Kebudayaan.

Kemdikbud. Modul Penguatan Literasi dalam Pembelajaran. Disampaikan dalam pendampingan Kurikulum K13 LPMP Kep. Bangka Belitung 1 Juni2016.

Matsuura, K. (2005). Education for All Global Monitoring Report 2006. France: Graphoprint.

Permendikbud Nomor 23 Tahun 2015 tentang penumbuhan budi pekerti melalui Gerakan Literasi Sekolah.

Rambousek, V., Štípek, J., \& Vaňková, P. (2016). Contents of Digital Literacy from the Perspective of Teachers and Pupils. Procedia. Social and Behavioral Sciences, 217, 354-362.

Supiandi. (2016). "Menumbuhkan Budaya Literasi di Sekolah dengan Program KITA", Simposium Guru Tahun 2016 Kementrian Pendidikan dan Kebudayaan Indonesia.

Suragangga, I. (2017). Mendidik Lewat Literasi untuk Pendidikan Berkualitas, Jurnal Penjaminan Mutu, Lembaga penjamin mutu Institut Hindu Dharma Negeri Denpasar, Vol. 3 No.2

Sutrisno, E. (2009). Manajemen Sumber Daya Manusia, Jakarta: Kencana. 
Mudarrisa: Jurnal Kajian Pendidikan Islam, Vol. 10, No. 2, 2018

Teguh, M. (2017). Gerakan Literasi di Sekolah Dasar, Prosiding Seminar Nasional aktualisasi kurikulum 2013 di sekolah dasar melalui gerakan literasi sekolah.

Wiedarti, P., et. al. (2016) Desain Induk Gerakan Literasi Sekolah, Jakarta: Dirjen. Pendidikan Dasar dan Menengah, Kemendikbud.

Yamtim, V., \& Wongwanich, S. (2014). A Study of Classroom Assessment Literacy of Primary School Teachers. Procedia - Social and Behavioral Sciences, 116, 2998-3004. 